\title{
T Lymphocyte Interaction with Immunoglobulin G Antibody in Systemic Lupus Erythematosus
}

\author{
Kunio Okudaira, Robert P. Searles, Kiyoaki Tanimoto, Yoshihiko Horiuchi, \\ and Ralph C. Williams, Jr., Department of Medicine, University of New \\ Mexico School of Medicine, Albuquerque, New Mexico 87131; Clinical \\ Research Division, Lovelace Medical Center, Albuquerque, New Mexico \\ 87108; Department of Medicine and Physical Therapy Faculty of Medicine, \\ University of Tokyo, 7-3-1 Hongo, Bunkyo-Ku, Tokyo, Japan
}

A B S T R A C T Systemic lupus erythematosus (SLE) is an autoimmune disease with multiple immune disturbances whose mechanisms remain unclear. We examined the interaction of antilymphocyte antibodies with cultured normal $\mathrm{T}$ lymphocytes. $\mathrm{T}$ cells were prepared by E-rosetting after petri-dish removal of adherent cells and cultured for 2-7 $\mathrm{d}$ in the presence of SLE sera or normal human sera. Cultured $T$ cells were washed and sonicated, and the amount of cellassociated IgG was quantitated by radioimmunoassay or enzyme-linked immunoassay (ELISA) methods. T cells cultured with 27 of 39 SLE sera showed marked increments of associated immunoglobulin G (IgG) although this was not observed with sera from mixed connective tissue disease patients containing high titers of ribonucleoprotein antibody or normal donors. The effective factors for IgG association in SLE sera were absorbed with normal peripheral blood lymphocytes or $\mathrm{T}$ cells. Anti-T cell IgG cytotoxic activity strongly correlated with $\mathrm{T}$ cell IgG association $(P<0.01)$.

$T$ cell-associated IgG was not removed by stripping of cell membrane IgG from living cells by acid buffer treatment; indirect immunofluorescence of cells fixed after 2-4 d of culture revealed cytoplasmic IgG staining. IgG anti-T cell antibodies appeared to associate inside the cell membrane or to penetrate into the cytoplasm of cells. $T$ cell $\mathrm{Fc}$ receptor blocking by heataggregated IgG or anti- $\beta_{2}$-microglobulin antibody did not alter IgG cell association. Since pepsin-digested SLE sera showed no $T$ cell association activity, whole IgG antibody molecules appeared to be necessary for interaction with cultured $T$ cells. In addition, reduction and alkylation of active SLE sera completely nullified $\mathbf{T}$ cell reactivity. When normal $\mathbf{T}$ cells were cultured with SLE sera showing marked IgG $\mathrm{T}$ cell

Received for publication 21 July 1981 and in revised form 22 December 1981. association, viability of cultured $T$ cells decreased rapidly after $4 \mathrm{~d}$, which suggests that IgG anti-T cell antibodies were associated with cell destruction. IgG cellassociating antilymphocyte antibodies present in SLE sera may cause $T$ cell disturbances in vivo and may be related to the lymphocytopenia present in SLE patients.

\section{INTRODUCTION}

Antilymphocyte antibodies (ALA) ${ }^{1}$ found in patients with systemic lupus erythematosus (SLE) have previously been characterized mainly as cold-reactive, complement-dependent antibodies of immunoglobulin $M$ (IgM) class (1-3). Whether cold-reactive antibodies can attach to target cells and actually eliminate certain lymphocyte subsets under in vivo conditions has remained unclear. Several studies of ALA in vitro have indicated that physiologically active factors may be present in IgG rather than IgM serum fractions; these include inhibition of mixed lymphocyte reaction (4, $5)$, interference with mitogen-induced lymphocyte transformation (6), as well as suppression of antibodydependent cellular cytotoxicity (7-9). We have previously reported that IgG ALA with specificity for T cells bearing IgG $\mathrm{Fc}$ receptors ( $\mathrm{T} \gamma$ cells) can prevent the generation of suppressor cells during in vitro Ig synthesis (10). Suppressor cell dysfunction in SLE has been recorded using a variety of in vitro systems by many investigators (11-16), and several recent reports suggest that this suppressor cell dysfunction may be

\footnotetext{
${ }^{1}$ Abbreviations used in this paper: ALA, antilymphocyte antibodies; ANA, antinuclear antibodies; ELISA, enzymelinked immunoassay; Ig, immunoglobulin; MCTD, mixed connective tissue disease; NHS, normal human sera; PBMC, peripheral blood mononuclear cells; PBS, phosphate-buffered saline; RNP, ribonucleoprotein; SLE, systemic lupus erythematosus; SRBC, sheep erythrocytes.
} 
directly related to ALA with suppressor cell specificity (17-21). However, all of the possible mechanisms associated with suppressor cell dysfunction in SLE have still not been clearly defined. The exact mode of cell membrane interaction of ALA and subsequent cellular response requires additional study. Recently AlarconSegovia et al. (22-24) reported that anti-ribonucleoprotein (RNP) antibodies in serum from patients with mixed connective tissue disease could penetrate viable cells via Fc receptors and thus block certain cellular functions. We were interested to learn whether ALA might show a similar mechanism in their reactivity with $\mathrm{T}$ cells.

The present study indicates that IgG anti-T cell antibodies in sera from SLE patients can closely associate with the cytoplasm of target cells and cause cell death without complement. IgG anti-T cell antibodies do not appear to associate with target cells via $\mathrm{Fc}$ receptors, although the intact whole IgG molecule is required for reactivity. The mechanism of cell interaction and association therefore seems to be different from those reported with anti-RNP antibody (22-24).

\section{METHODS}

Clinical material. Serum samples were collected from 39 patients with SLE. All patients met the American Rheumatism Association criteria for the diagnosis of definite SLE (25). Control sera were obtained from 18 normal donors of both sexes, ages 20-35; in addition, sera from patients with mixed connective tissue disease (MCTD) and high titers of antibody to RNP were also studied as controls in several instances. All sera studied were heat inactivated at $56^{\circ} \mathrm{C}$ for $30 \mathrm{~min}$ before testing.

Lymphocyte preparation. Peripheral blood mononuclear cells (PBMC) were separated from heparinized blood obtained from normal donors by differential centrifugation over Ficoll-Hypaque (26). After removal of adherent cells by incubation on petri dishes for $45 \mathrm{~min}$ at $37^{\circ} \mathrm{C}$, PBMC were mixed with neuraminidase-treated sheep erythrocytes (SRBC) to form E rosettes. Rosetted cells and nonrosetting cells were separated by differential centrifugation on FicollHypaque and SRBC contained in the rosette-forming fractions lysed with ammonium choride-Tris buffer. Neuraminidase E-rosetted cells showed no more than $1 \%$ of cells with surface Ig. Peroxidase stains of these preparations in parallel showed $<2 \%$ of positive cells. To prepare $\mathrm{T} \gamma$ and non-T $\gamma$ cell preparations, ox erythrocytes were sensitized with rabbit anti-ox IgG antibody and mixed with separated $T$ cell fractions to form EA rosettes. Rosette-forming cells ( $T \gamma$ cells) and non-T $\gamma \mathrm{T}$ cells were then separated by differential centrifugation on Ficoll-Hypaque and ox erythrocytes contained in the rosetting fractions lysed with ammonium chlorideTris buffer. Separated $T \gamma$ and non-T $\gamma$ T cells were then used as targets in microcytotoxicity studies. $T \gamma$ cell preparations showed $60-80 \% \mathrm{~T} \gamma$ rosette-forming cells and $<2 \%$ peroxidase positive cells: non- $\mathrm{T} \gamma$ cell preparations showed $<1 \% \mathrm{~T} \gamma$ rosette-forming cells and $<1 \%$ peroxidase positive cells.

Microcytotoxicity assay. Serum samples from control or connective tissue disease patients were studied for $T$ cell subset specificity as previously described (27) by means of the microcytotoxicity assay of Terasaki and McClelland (28). To remove IgM ALA from test sera, serum samples in many instances were incubated for $120 \mathrm{~min}$ at $4^{\circ} \mathrm{C}$ with Sepharose conjugated to specific rabbit antihuman IgM. Supernatant serum was separated from Sepharose beads by centrifugation at 2,000 rpm for $5 \mathrm{~min}$, and Ig remaining after absorption quantitated by single radial immunodiffusion. Microcytotoxicity testing of sera involved incubation of target cells and serum at $15^{\circ} \mathrm{C}$ for $30 \mathrm{~min}$, followed by an additional 3-h incubation with undiluted rabbit complement at $15^{\circ} \mathrm{C}$. The percentage of killing was enumerated under phase contrast microscopy. SLE and other connective tissue disease sera were classified as to relative microcytotoxicity specificity with $\mathrm{T} \gamma$ and non-T $\gamma \mathrm{T}$ cells as targets. Killing of $\geq 30 \%$ was classified as positive and cytotoxicity $<20 \%$ as negative. Some test SLE sera showed $\geq 30 \%$ killing with both $\mathrm{T} \gamma$ and non-T $\boldsymbol{\gamma} T$ cells; others showed killing primarily against $T \gamma$ cells, and an additional group appeared to show cytotoxicity mainly with non- $\boldsymbol{T} \boldsymbol{\gamma} \mathrm{T}$ cells.

Studies of normal test lymphocyte interaction with SLE sera. $2 \times 10^{6}$ freshly prepared $\mathrm{T}$ cells from normal donors were incubated at $37^{\circ} \mathrm{C}$ in humidified $5 \% \mathrm{CO}_{2}$-air in $1 \mathrm{ml}$ RPMI 1640 containing test serum samples diluted fivefold (final serum concentration $20 \%$ ). Test lymphocytes were incubated with SLE or normal serum dilutions for extended periods up to $7 \mathrm{~d}$. Aliquots of lymphocyte-serum mixtures were assayed in parallel for viability with trypan blue supravital staining. After various intervals in culture, $T$ cells were harvested and washed three times with Hanks' balanced salt solution and adjusted to $1 \times 10^{6} / \mathrm{ml}$ in RPMI 1640 containing $10 \%$ fetal calf serum. Living cell suspensions were examined directly under phase-contrast microscopy with an indirect immunofluorescence technique with $\mathrm{F}(\mathrm{ab})^{\prime}{ }_{2}$ rabbit or goat antihuman IgG or IgM. In addition, in some experiments an attempt was made to strip living lymphocyte membranes of surface $\mathrm{Ig}$ with low $\mathrm{pH}$ buffers $(0.05 \mathrm{M}$ acetate, $\mathrm{pH} 4.0$ ) and subsequent 1 -min incubation at $1^{\circ} \mathrm{C}$ followed by washing as previously described (29). In addition, cell suspensions were washed three times with Hanks' balanced salt solution and smeared on glass slides, dried in air, and then fixed with $95 \%$ ethanol. After washing with phosphate-buffered saline (PBS), fixed cells were stained with fluorescein isothiocyanate-labeled rabbit antihuman IgG or IgM (Behring-Werke AG, Marburg/Lahn, West Germany) and examined under fluorescence microscopy.

Measurement of IgG and IgM in supernate from sonicated cells. Because indirect immunofluorescence appeared to indicate immunoglobulin from SLE sera closely associated with or even inside cell membranes, a number of attempts to define cell-associated Ig were made. After various times of incubation, T cells were harvested, washed as described above, and sonicated. After sonication, cell sonicates were centrifuged at $2,000 \mathrm{rpm}$ for $10 \mathrm{~min}$ and supernate collected for immunoassay of Ig. Ig levels in supernate from sonicated cells were measured by radioimmunoassay and by an ELISA method. The method for Ig determination by radioimmunoassay has previously been described in detail (30). The ELISA method used flat-bottom flexible microtiter plates (Cooke Engineering Co., Alexandria, VA) for solid phase ELISA assay. $100 \mu \mathrm{l}$ of purified IgG or IgM $(10 \mu \mathrm{g} / \mathrm{ml}$ in PBS containing $0.01 \%$ sodium azide) was placed in the wells. Plates were incubated $30 \mathrm{~min}$ at $37^{\circ} \mathrm{C}$ and overnight at $4^{\circ} \mathrm{C}$. After incubation, the wells were washed three times with PBS and dipped in gelatin buffer (PBS, $0.3 \%$ gelatin, $0.01 \%$ sodium azide). After $2 \mathrm{~h}$ at room temperature, plates were washed once with PBS-Tween (80) (Matheson Coleman \& Bell, East Rutherford, NJ) buffer and twice with PBS. 50 $\mu \mathrm{l}$ of supernate was added to the wells and $50 \mu \mathrm{l}$ of peroxidase conjugated anti-IgG or anti-IgM (Tago, Inc., Burlingame, 
CA) was added. Plates were incubated $30 \mathrm{~min}$ at $37^{\circ} \mathrm{C}$ and $2 \mathrm{~h}$ at $4^{\circ} \mathrm{C}$. Wells were then washed once with PBS-Tween buffer and twice with PBS. After washing, $100 \mu \mathrm{l}$ of the substrate-0.02\% 2.2-Azino-di-[3-athylbenzthiazolin-sulfonate (6)] in $2.3 \%$ citric acid buffer, $\mathrm{pH} 4.0$, with $0.17 \%$ hydrogen peroxidase-was added to the wells. After $30-\mathrm{min}$ incubation at room temperature, the reaction was stopped by adding citric acid buffer, $\mathrm{pH}$ 2.8. The light absorbance of wells was measured by a photometer and IgG or IgM concentration calculated from standard curves prepared from purified Ig preparations.

Special studies of Ig-lymphocyte interaction. Since it seemed possible that close IgG association with test cells might be influenced by cell membrane Fc receptors, several special studies were conducted. Aggregated human IgG prepared by $20-\mathrm{min}$ incubation of IgG at $60^{\circ} \mathrm{C}$ or rabbit antihuman $\beta_{2}$ microglobulin antisera (Dakoplats, Accurate Chemical \& Scientific Corp., Westbury, NY) were added to normal human $\mathrm{T}$ cells. After preincubation at $37^{\circ} \mathrm{C}$ for 30 min, test serum samples were then added. Anti- $\beta_{2}$ microglobulin was used, since it had been previously demonstrated that this reagent appeared to inhibit $F c$ receptor function in vitro (31). In addition, in some experiments $T$ cells were preincubated with colchicine $(10 \mu \mathrm{m})$ or cytochalasin B (10 $\mu \mathrm{g} / \mathrm{ml}$, Sigma Chemical Co., St. Louis, MO) for $30 \mathrm{~min}$ at $37^{\circ} \mathrm{C}$ before test serum samples were added.

Several special studies were performed in an attempt to define cultured $\mathrm{T}$ cell Ig binding. SLE sera showing high binding were pepsin digested as previously described (32) and tested subsequently for lymphocyte interaction. In addition, some sera were reduced with $0.01 \mathrm{M}$ dithiothreitol at room temperature for $30 \mathrm{~min}$ and alkylated with 0.015 $\mathrm{M}$ iodoacetamide at $0^{\circ} \mathrm{C}$ for $2 \mathrm{~h}$. After reduction and alkylation, sera were dialysed against PBS overnight before retesting.

Special studies with living and dead cells. Cultured T cells were fractionated by discontinuous density gradient centrifugation using polyvinylpyrolidone coated colloidal silica (Percoll, Pharmacia Fine Chemicals, Div. Pharmacia Inc., Piscataway, NJ) as previously described (31). Briefly, the heterogeneous population of cells was mixed in isotonic solution, referred to as $100 \%$ Percoll solution. Sequential dilutions of 60,50 , and $20 \%$ solutions made by adding 0.15 M PBS to the $100 \%$ solution were carefully layered over the $100 \%$ solution containing the cells. The density of each layer was determined with density marker beads (Pharmacia). The $100 \%$ layer measured 1.121 buoyant density $(\mathrm{g} / \mathrm{ml})$, the $60 \%$ layer 1.076 , the $50 \%$ layer 1.062 , and the $20 \%$ layer 1.033 . Centrifugation was carried out at $450 \mathrm{~g}$ for $20 \mathrm{~min}$ at $4^{\circ} \mathrm{C}$.

\section{RESULTS}

We observed the cytoplasmic staining patterns of cultured $T$ cells in the presence of SLE sera using the indirect immunofluorescence method. When suspensions of living cells were examined, occasional cells showing surface membrane immunofluorescence were seen; when the same populations of cells showing $>80 \%$ viability by supravital staining were cytocentrifuged and fixed with ethanol, 20-30\% striking immunofluorescence of cytoplasm was noted. After $2 \mathrm{~d}$ of culture with SLE serum, fixed T cells were stained with antihuman Ig (Fig. 1). As noted above, the cytoplasm of $T$ cells seemed to be filled with IgG; more- over, no staining of nuclei was seen. Staining for IgM showed a much weaker, more diffuse pattern in all instances. In such preparations $50-90 \%$ of cultured $T$ cells showed cell-associated IgG by these immunofluorescence procedures after $3 \mathrm{~d}$. Only $10-20 \%$ of cultured cells showed staining for cell-associated IgM under parallel conditions. Control observations using rabbit antihuman serum albumin conjugated with fluorescein isothiocyanate showed no cell staining in parallel experiments using either NHS or test SLE sera after similar periods of incubation. No effect of heat inactivation of SLE sera on IgG cell association or cytotoxic effect in long-term culture was noted. These initial immunofluorescence studies of normal human $T$ cells incubated with SLE serum suggested a close association between IgG from some SLE sera and cytoplasmic components of cultured $\mathrm{T}$ cells.

It was not clear, however, whether this cytoplasmic staining of test $T$ cells had occurred with living cells, since fixation preceded the latter immunofluorescence procedure. To answer this question, time sequence studies were conducted for IgG $\mathrm{T}$ cell association and cell viability. No significant difference in cultured cell viability was recorded between test cells in SLE or NHS for the first $4 \mathrm{~d}$ in such cultures (Fig. 2A). However, IgG association with T cells in SLE sera occurred as rapidly as $30 \mathrm{~min}-3 \mathrm{~h}$ and increased during the subsequent 4-d culture period (Fig. 2B). Thereafter, a more rapid decrease in residual cell viability was noted in the presence of SLE sera as compared with normal control sera (Fig. 2A). Since the original viability of freshly prepared $T$ cells was $\geq 98 \%$, it would appear that IgG T cell association had occurred with intact living $\mathrm{T}$ cells. The viability was not changed after short culture periods of $30 \mathrm{~min}-3 \mathrm{~h}$, during which time clearcut IgG cell association was occurring as noted above.

In additional experiments, $T$ cells cultured in the presence of SLE sera or normal human sera (NHS) for $3 \mathrm{~d}$ were fractionated by discontinuous density gradient centrifugation on Percoll gradients, where a majority of dead cells float, and the viability, percentage of cytoplasmic IgG-staining cells, and the amount of $\mathrm{T}$ cell-associated Ig were examined (Table I). Four different layers were found: fraction 1 at the top, fraction 2 at the 1.075 density, fraction 3 at 1.121 , and fraction 4 (pellet) as shown in Table I. Fraction 1 contained the greatest volume of dead cells and had the largest amount of cytoplasmic staining and IgG-T cell association. However, in SLE serum 1, fractions 3 and 4, containing large numbers of viable cells had significant amounts of cytoplasmic staining and IgG association. In particular, fraction 3 with $3 \%$ dead cells had $30 \%$ cytoplasmic IgG positive cells and $754 \mathrm{ng} /$ $10^{6}$ cells IgG association. Similar results were recorded 

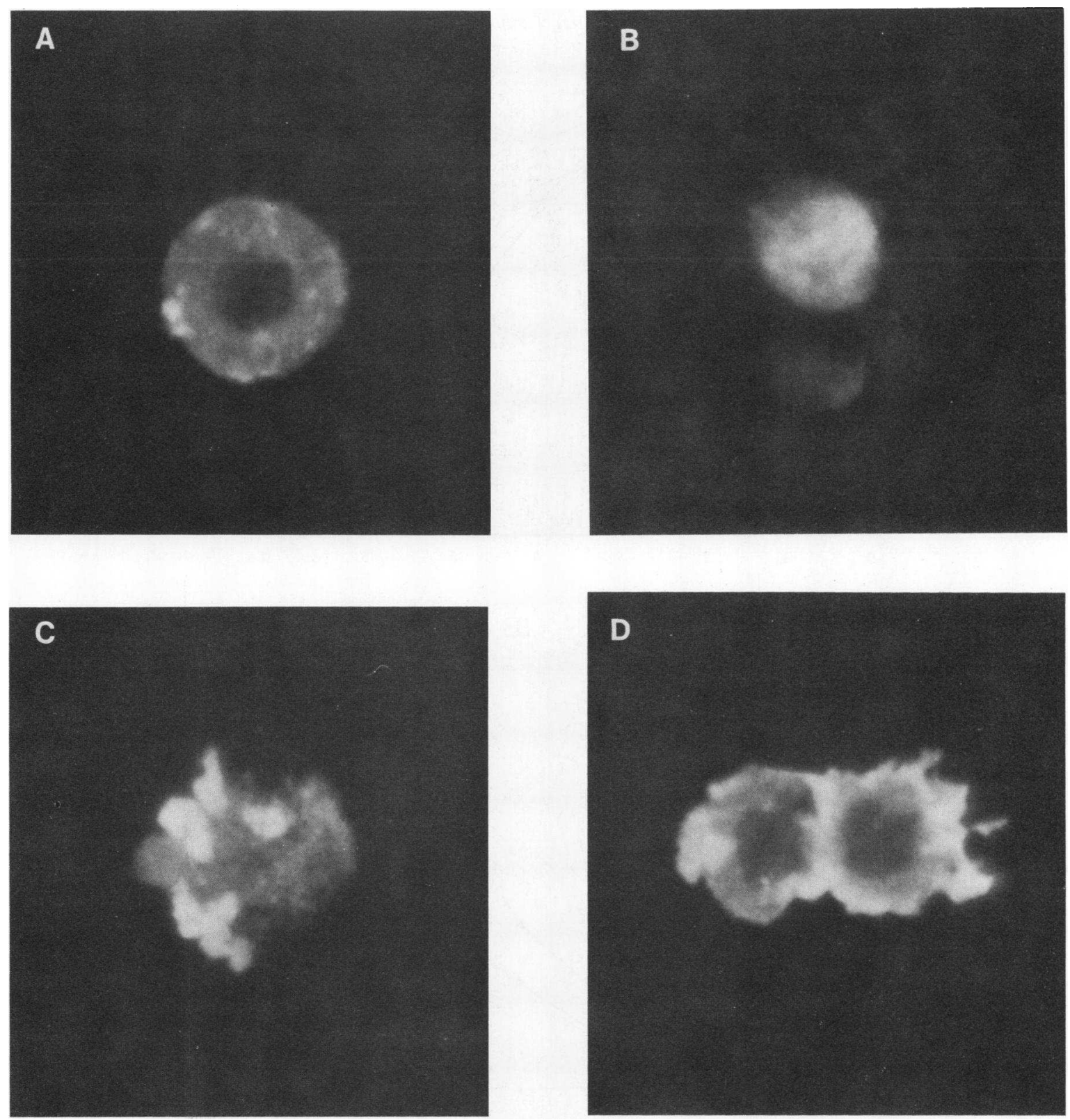

FIgURE 1 After $2 \mathrm{~d}$ of culture with SLE sera, T cells were fixed and stained with antihuman IgG (A). The cytoplasm of $T$ cells seemed to be filled with IgG and the nucleus was excluded. On the contrary, when $T$ cells were stained with antihuman IgM (B), the staining patterns were very different. $T$ cells were stained only diffusely with antihuman IgM (magnification $\times 1,000$ ). After $4 \mathrm{~d}$ of culture, when $\mathrm{T}$ cells were stained with fluorescein isothiocyanate-labeled antihuman IgG, IgG in cytoplasm of $\mathrm{T}$ cells was concentrated and showed a granular deposit pattern (C, D). These results suggested that only IgG in SLE sera was closely associated with cytoplasm of $T$ cells (magnification $\times 1,000$ ).

in the case of SLE serum 2. On the other hand, T cells cultured with NHS showed no significant cytoplasmic IgG staining and IgG $\mathrm{T}$ cell association. These data suggested that IgG association had occurred with the intact living cells and was not nonspecific binding of IgG by dead cells.

We examined the amount of Ig associated with cultured normal $T$ cells using sera from patients with 

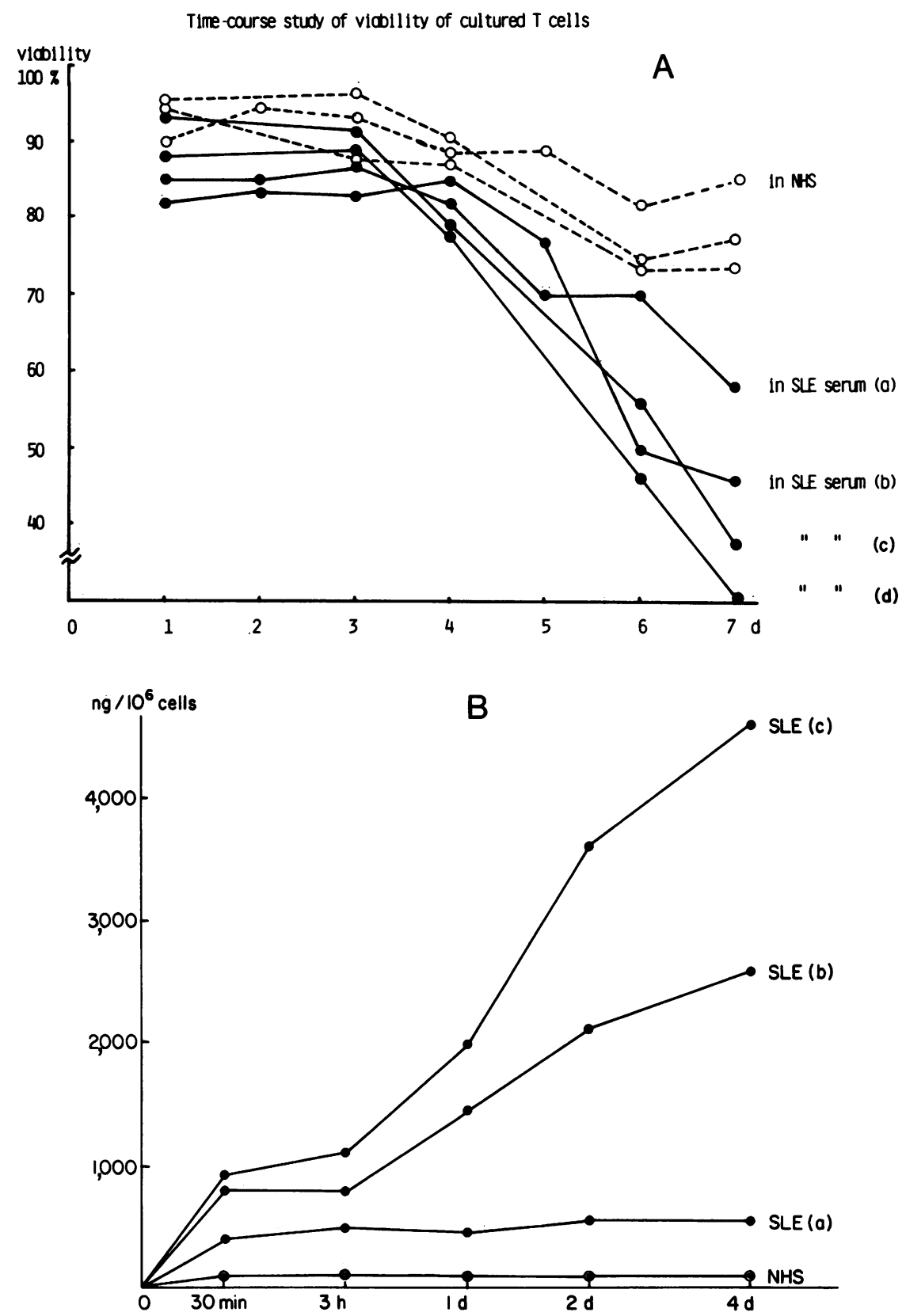

Figure 2 (A) Relative viabilities of normal T cells cultured with NHS or SLE sera. SLE sera (b, c, and d) contained strong reactivity of IgG ALA, whereas much less was detectable in SLE serum (A). The viabilities of freshly prepared original $T$ cells were $\geq 98 \%$. (B) Time-sequence studies of $\mathrm{T}$ cell IgG association.

mixed connective tissue disease that were antinuclearantibody (ANA) positive but that showed no significant anti-T cell antibody. In parallel, 17 sera from SLE patients that were ANA positive and anti-T cell antibody positive were also studied. All of the sera from patients with mixed connective tissue disease showed high titers of anti-RNP antibody. This experiment was therefore designed to assess whether IgG cell association might be occurring through mechanisms similar to those previously described by Alarcon-Segovia et al. (22-24). As shown in Table II, when normal T cells were cultured for $3 \mathrm{~d}$ in the presence of whole, inac- 
TABLE I

Analysis of T Cells Separated by Centrifugation over Percoll Density Gradient after 3-d Incubation with SLE or NHS

\begin{tabular}{|c|c|c|c|c|c|c|}
\hline $\begin{array}{l}\text { Serum } \\
\text { sample }\end{array}$ & Fractions & $\begin{array}{l}\text { Percentage of } \\
\text { total cells }\end{array}$ & $\begin{array}{l}\text { Dead } \\
\text { cells }\end{array}$ & $\begin{array}{l}\text { Cytoplasmic } \\
\text { IgG staining }\end{array}$ & $\lg G$ & IgM \\
\hline & & $\%$ & $\%$ & $\%$ & \multicolumn{2}{|c|}{$\mathrm{ng} / 1 \times 10^{6}$ cells } \\
\hline \multirow[t]{4}{*}{ SLE-1 } & Top 1 & 16.7 & 67 & 60 & 2,800 & 130 \\
\hline & 2 & 55.2 & 8 & 15 & 430 & 36 \\
\hline & 3 & 8.3 & 3 & 30 & 754 & 65 \\
\hline & Pellet 4 & 19.8 & 16 & 40 & 770 & 54 \\
\hline \multicolumn{3}{|c|}{ Whole unfractionated cells } & 13 & 25 & 1,200 & 60 \\
\hline \multirow[t]{4}{*}{ SLE-2 } & Top 1 & 14.9 & 66 & 35 & 2,400 & 107 \\
\hline & 2 & 50.5 & 11 & 7.5 & 284 & 30 \\
\hline & 3 & 20.5 & 7 & 15 & 416 & 62 \\
\hline & Pellet 4 & 14.1 & 22 & 30 & 1,980 & 87 \\
\hline \multicolumn{3}{|c|}{ Whole unfractionated cells } & 19 & 22 & 1,400 & 65 \\
\hline \multirow[t]{4}{*}{ NHS } & Top 1 & 9.8 & 30 & 2.5 & 23 & 4 \\
\hline & 2 & 68.4 & 1 & 0 & 14 & 0 \\
\hline & 3 & 8.4 & 4 & 0.5 & $<10$ & 0 \\
\hline & Pellet 4 & 13.3 & 25 & 0.5 & 33 & 33 \\
\hline \multicolumn{3}{|c|}{ Whole unfractionated cells } & 6 & 0.5 & 23 & 15 \\
\hline
\end{tabular}

tivated SLE sera containing strong reactivity for anti$T$ cell antibodies, upon washing and sonication large amounts of IgG were released into the supernate. On the contrary, when $T$ cells were cultured in the presence of sera without significant anti-T cell antibody, amounts of IgG quantitated after cell disruption were essentially the same as those noted after incubation with NHS. No relationship was recorded between amount of IgG associated with incubated cells and titers or presence of anti-RNP antibody. Of 17 SLE sera studied in Table II, IgG cell association 2 SD above the mean of normal controls was observed in 11 instances after culturing with lymphocytes. In addition, 27 of 39 SLE sera studied during subsequent work showed IgG cell-association effect $2 \mathrm{SD}$ above that of 18 normal controls.

The amount of cell-associated IgM was low both in presence of SLE or normal control sera. These results suggested that anti-T cell antibodies as estimated by cytotoxicity might be related to the IgG association with $T$ cells. To explore this possibility, several absorption experiments were done on normal PBMC, $T$ cells, human erythrocytes, and SRBC. As shown in Table III, whole test SLE sera showed strong IgG cellassociation effect of $1,700 \mathrm{ng} / \mathrm{ml}$ and $3,200 \mathrm{ng} / \mathrm{ml}$, although the effect was almost completely removed after prior absorption with PBMC or $T$ cells, but not with human erythrocytes or SRBC. These results indicated that anti-T cell antibodies were mainly in- volved in the IgG cell-association effect in SLE sera. However, considering the fact that non-T cells could also absorb out the effective factors, it may be that common antigens shared by both $T$ and non- $T$ cells might also be involved in this reaction.

The correlation between anti-T cell cytotoxic activity and IgG cellular adherence effect was examined. In Fig. $3 \mathrm{~A}$ the possible relationship between whole serum anti-T cell cytotoxic activity and IgG cell-association is depicted graphically. No clearcut significant correlation was recorded $(n=32, v=0.372, P$ $>0.05$ ). After removal of IgM from sera by affinity immunoabsorbents, the correlation between IgG anti$T$ cell cytotoxic activity and IgG cell association is ploted (Fig. 3B) $(P<0.01, r=0.829)$. These data strongly suggested that IgG anti-T cell cytotoxic antibody appeared to correlate closely with IgG association with $T$ cells.

Next, to examine whether cellular association of Ig was restricted to particular $T$ cell subsets, we classified SLE sera according to the remaining cytotoxicity after removal of IgM by anti-IgM affinity chromatography and examined their IgG cell-association effects (Table IV). Sera that contained both IgG anti-T $\gamma$ cell antibody and IgG anti-non- $T \gamma$ cell antibody showed the strongest IgG cell-association effects $(3,475 \pm 2,227 \mathrm{ng} / \mathrm{l}$ $\times 10^{6}$ cells). Sera that contained only anti-T $\gamma$ cell antibody showed 1,147 $\pm 355 \mathrm{ng}$ IgG association, and sera that contained only IgG anti-non-T $\gamma$ cell antibody 
TABLE II

$T$ Cell-associated Ig in Whole Sera from SLE and MCTD Patients after Culture with Cells for $3 d$

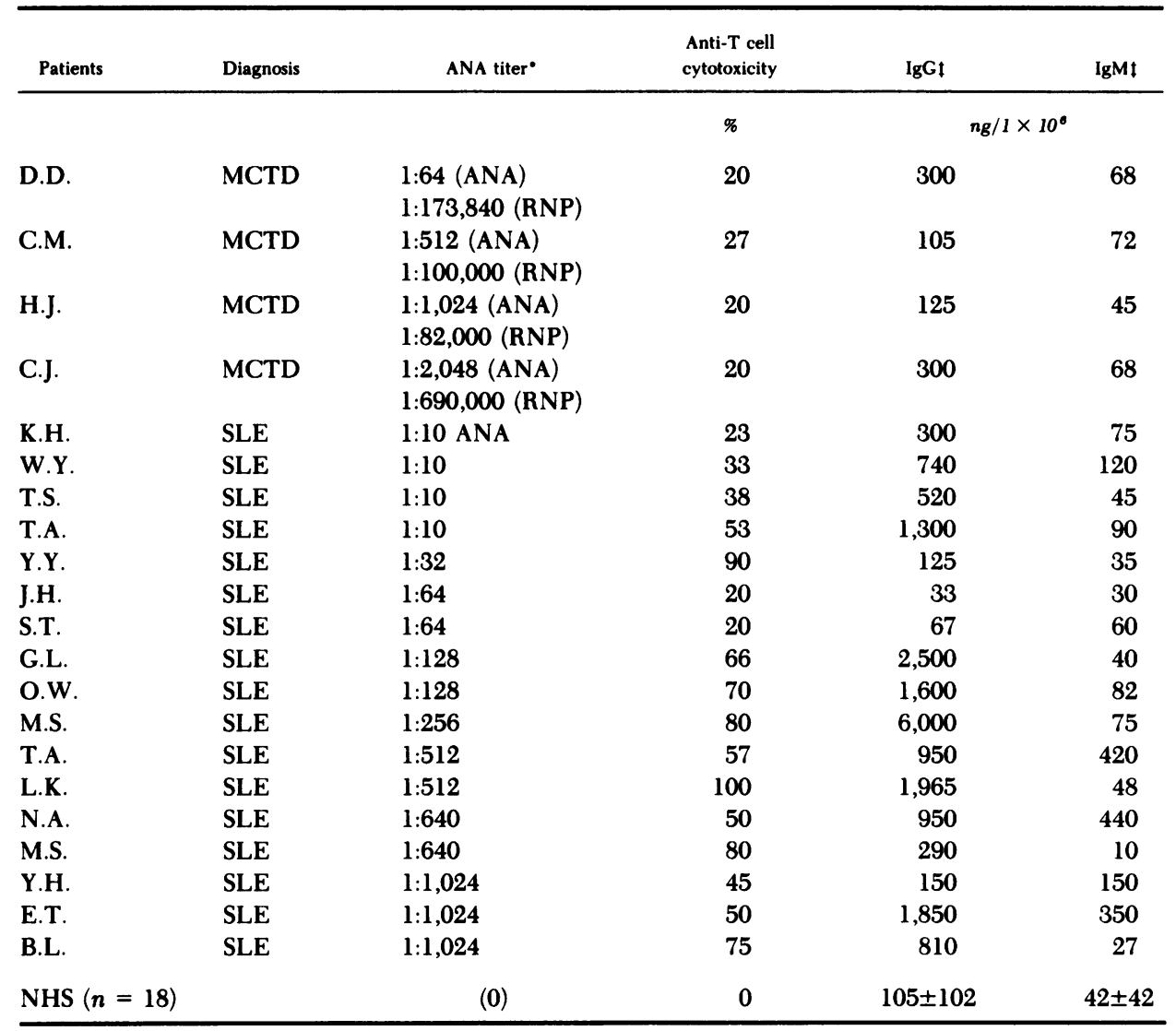

-ANA titers are given for standard ANA obtained with mouse liver sections; in the case of patients with MCTD, anti-RNP titers were measured by hemagglutination assay.

\Purified T cells were cultured with sera test sera for $3 \mathrm{~d}$. After culture, $\mathrm{T}$ cells were washed and ultrasonicated. IgG and IgM released into the supernate was measured by ELISA and radioimmunoassay, and expressed as nanograms of $\mathrm{Ig}$ per $10^{6}$ cultured cells.

showed $823 \pm 263 \mathrm{ng}$ IgG cell association. Sera that contained no IgG antibody against $T$ cell subsets showed only a weak IgG association of $388 \pm 284 \mathrm{ng}$. These results suggested that both IgG anti-T $\gamma$ cell antibodies and IgG antibodies against non-T $\gamma$ cells were present in sera showing IgG cell association effect. In additional experiments, we cultured separated $\mathrm{T} \gamma$ cells and non-T $\gamma$ cells with SLE sera or NHS and measured Ig cell association. In confirmation of the data shown in Table IV, SLE sera reacted with both separated T cell subsets, and in most instances showed higher amounts of IgG associated with $\mathrm{T} \gamma$ than with non-T $\gamma \mathrm{T}$ cells.

Since prolonged incubation of test $T$ lymphocytes appeared to be followed by close association and possible endocytosis or penetration of cells particularly by IgG, several parallel experiments were performed. Cultured $\mathrm{T}$ cells were treated with $0.05 \mathrm{M}$ acetate buffer, $\mathrm{pH} 4.0$, containing $0.85 \mathrm{M} \mathrm{NaCL}, 0.05 \mathrm{M}$ KCL, and $0.03 \%$ human albumin at $0^{\circ} \mathrm{C}$ for $1 \mathrm{~min}$. Cells were then washed twice with cold PBS and viabilities, and surface IgG and cell-associated IgG were then examined in an attempt to ascertain whether IgG found in sonicates of cells incubated with serum was detectable as externally membrane bound in living cells after acid buffer stripping. As a positive control, we used monoclonal mouse anti-T cell antibodies reacting with normal human T cells (OKT3, OKT4, and OKT8). Acid treatment effectively removed membrane bound antibodies in all cases. Results of such experiments are shown in Table V. Acid treatment of cultured cells showed marked diminution in detectable cell surface Ig, as viewed by immunofluorescence of living cells, but no significant change was noted in total cell-associated IgG as measured in sonicates before and 
TABLE III

Absorption Experiments of SLE Sera

\begin{tabular}{|c|c|c|c|}
\hline & Absorbed with & IgG & IgM \\
\hline & & \multicolumn{2}{|c|}{$\mathrm{ng} / 1 \times 10^{6} \mathrm{cells}$} \\
\hline \multirow[t]{4}{*}{ SLE $1^{\circ}$} & $(-)$ & 1,700 & 420 \\
\hline & PBMC & 480 & 250 \\
\hline & Human erythrocytes & 2,000 & 460 \\
\hline & SRBC & 2,000 & 460 \\
\hline \multirow[t]{3}{*}{ SLE $2^{\circ}$} & $(-)$ & 3,200 & 220 \\
\hline & $\mathrm{T}$ cells & 180 & 130 \\
\hline & Non-T cells $₫$ & 700 & 180 \\
\hline
\end{tabular}

- Two representative SLE sera were absorbed with several cell types at the concentration of $1 \times 10^{8}$ cells $/ \mathrm{ml}$ for $2 \mathrm{~h}$ at $4^{\circ} \mathrm{C}$. Unabsorbed sera and absorbed sera were examined for the capacity to associate with $T$ cells. Only PBMC, $T$ cells, or non- $T$ cells could absorb the effective factors.

\ Non-T cells refer to lymphocyte populations not rosetted by neuraminidase $T$ cell rosettes ( $B$ cells and null cells).

after membrane IgG stripping. These results indicated that Ig associated with $T$ cells after culture had entered the cell membrane, or was so closely associated with

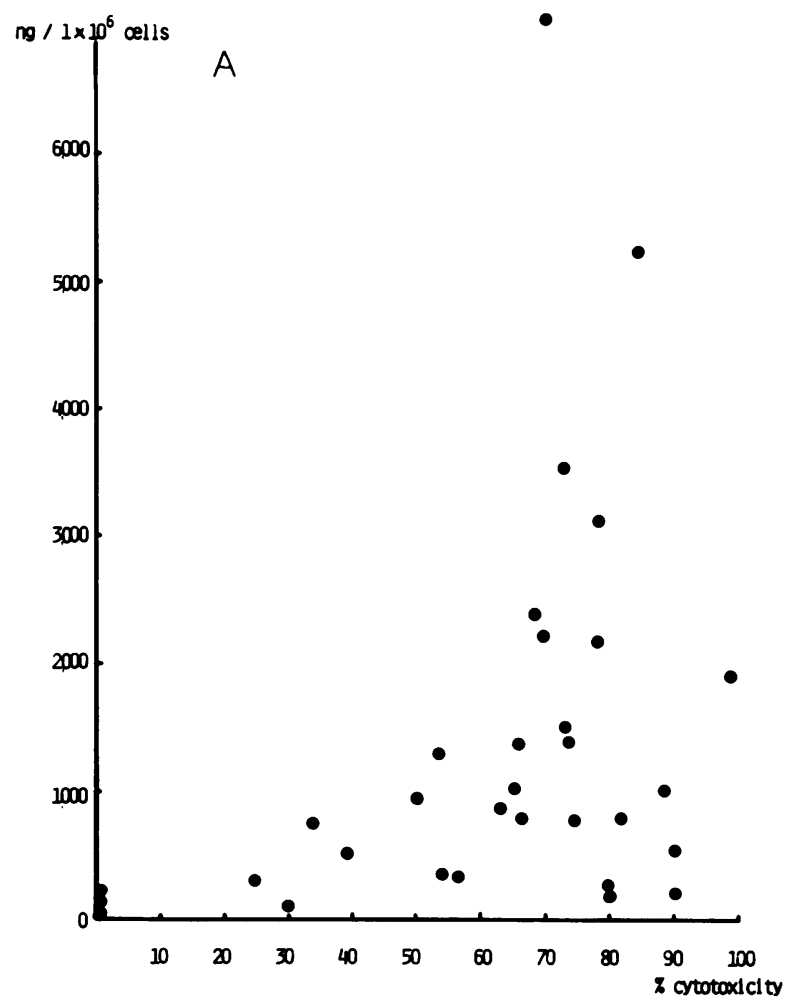

TABLE IV

Different Types of ALA Can Associate with T Cells

\begin{tabular}{|c|c|c|c|c|c|}
\hline \multirow{2}{*}{$\begin{array}{l}\text { Serum } \\
\text { source }\end{array}$} & \multicolumn{2}{|c|}{ IgG ALA } & \multirow{2}{*}{$\begin{array}{l}\text { Patient } \\
\text { sera } \\
\text { studied }\end{array}$} & \multicolumn{2}{|c|}{ Ig concentration! } \\
\hline & Anti-T $\gamma^{\bullet}$ & Anti-non-T$\gamma^{\bullet}$ & & IgG & IgM \\
\hline & & & $n$ & $n g / 1 \times$ & cells \\
\hline \multirow[t]{4}{*}{ SLE } & $(+)$ & $(+)$ & 6 & $3,475 \pm 2,227$ & $246 \pm 164$ \\
\hline & $(+)$ & $(-)$ & 3 & $1,147 \pm 355$ & $100 \pm 17$ \\
\hline & $(-)$ & $(+)$ & 3 & $823 \pm 263$ & $83 \pm 48$ \\
\hline & $(-)$ & $(-)$ & 6 & $388 \pm 284$ & $56 \pm 49$ \\
\hline NHS & $(-)$ & $(-)$ & 18 & $105 \pm 102$ & $42 \pm 42$ \\
\hline
\end{tabular}

- SLE serum samples were classified according to the remaining cytotoxicity against $\mathrm{T} \boldsymbol{\gamma}$ or non-T $\boldsymbol{\gamma}$ cells, after removal of IgM by affinity chromatography. Killing of $\geq 30 \%$ was classified as positive and cytotoxicity $<20 \%$ as negative. Sera classified as to $T$ cell subset cytotoxicity were studied for Ig cell association.

t Mean \pm SD.

cellular components that acid elution had not resulted in dissociation.

We further examined the relationship of $\mathrm{T}$ cell $\mathrm{Fc}$ receptors to the IgG cell interaction with $\mathrm{T}$ cells, using blocking experiments with aggregated IgG and anti-

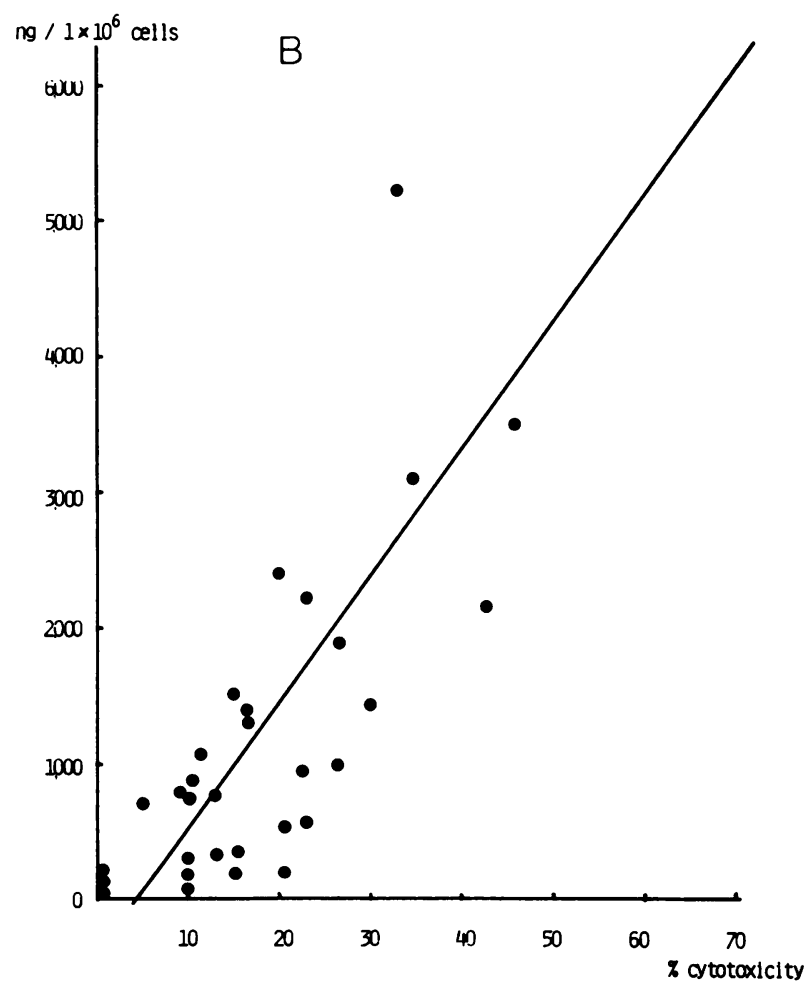

FIGURE 3 (A) Relationship between cytotoxicity of anti-T cell ALA and IgG association with $T$ cells $(n=32, t=0.372, P>0.05)$. (B) Plot of relationship between cytotoxicity of anti-T cell ALA after absorption on anti-IgM immunoabsorbent and IgG association with T cells ( $n$ $=32, r=0.829, P<0.01)$. 
TABLE V

Effect of Acid Treatment of Cultured T Cells on IgG Association

\begin{tabular}{lcccc}
$\begin{array}{lccc}\text { (A) } \\
\text { Sera }\end{array}$ & $\begin{array}{c}\text { Acid } \\
\text { treatment }\end{array}$ & Viability & $\begin{array}{c}\text { Cell } \\
\text { surface IgC }\end{array}$ & $\begin{array}{c}\text { T cell-associated } \\
\text { IgG }\end{array}$ \\
\hline \multirow{2}{*}{ SLE 1 } & & $\%$ & & $n g / 1 \times 10^{\circ}$ cells \\
& $(-)$ & 73 & 9 & 440 \\
SLE 2 & $(+)$ & 77 & 3 & 560 \\
& $(-)$ & 85 & 7.5 & 1250 \\
SLE 3 & $(-)$ & 81 & 1 & 1100 \\
& $(+)$ & 78 & 13 & 2300 \\
NHS & $(-)$ & 78 & 3 & 2500 \\
& $(+)$ & 78 & 0 & 66
\end{tabular}

(B)

\begin{tabular}{ll} 
Monoclonal & $\begin{array}{c}\text { Positive cells on } \mathbf{T} \text { cells with } \\
\text { or without acid treatment }\end{array}$ \\
\hline antibodies & $(-)$
\end{tabular}

$\%$

$\begin{array}{lll}\text { OKT3 } & 84 & 2 \\ \text { OKT4 } & 64 & 3 \\ \text { OKT8 } & 25 & 5\end{array}$

Purified T cells were sensitized with OKT3, OKT4, and OKT8 and percentages of positive cells were assayed by rosette technique with goat-antimouse-IgG-conjugated ox erythrocytes with or without acid treatment.

sera to $\beta_{2}$ microglobulin as well as pepsin digestion or reduction and alkylation of SLE sera. The effect of heat-aggregated IgG on IgG cell association was examined by preculturing $T$ cells with aggregated IgG before culture with SLE sera. As shown in Table VI, there was no effect of aggregated IgG on cell IgG association. In addition, the effect of rabbit antihuman $\beta_{2}$ microglobulin antibody was examined. As a preliminary experiment, the $\mathrm{Fc}$ receptor blocking effect of this antibody was demonstrated. As shown in Table VI, rabbit anti- $\beta_{2}$ microglobulin antibody showed complete $\mathrm{Fc}$ receptor blocking effect at 1:1,000 dilution. The effect of this antibody on IgG cell association is also shown in Table VII. Fc receptor blocking by anti$\beta_{2}$ microglobulin resulted in no diminution or subsequent demonstrable effect on IgG cell association.

In additional experiments we examined the effect of pepsin digestion as well as reduction and alkylation of whole reactive SLE sera. As shown in Table VIII, the ability of SLE sera previously shown to associate closely with $T$ cells was completely nullified by pepsin digestion. In addition, reduction and alkylation of sera completely eliminated $\mathrm{T}$ cell association effect. Whole IgG antibody molecules therefore appeared to be necessary for association with $T$ cells.

The effect of cytochalasin B and colchicine on isolated $\mathrm{T}$ cells was tested by preincubation with cytochalasin $\mathrm{B}$ or colchicine at $37^{\circ} \mathrm{C}$ for $30 \mathrm{~min}$ and serum samples were then added to the $\mathrm{T}$ cell preparations. Results shown in Table IX indicated that colchicine had either no or only a slight enhansive effect on IgG cell association and that cytochalasin B had a marked enhancing effect. In these experiments, cell viability was maintained at $80 \%$.

\section{DISCUSSION}

The present studies indicate a striking affinity between cultured normal $\mathrm{T}$ lymphocytes and IgG ALA present in some SLE sera. Initial monitoring of this reaction by serial viability and direct immunofluorescence study appeared to indicate that IgG associated closely with the cytoplasm of cultured lymphocytes. It appeared as if the IgG associated with $T$ cells in these instances might actually be present within lymphocyte membranes. This was supported by the comparative studies of cell surface Ig immunofluorescence after acid washing of cultured cells and quantitation of $\mathrm{Ig}$ present in cell sonicates. Thus, depletion of cell surface membrane Ig by acid washing was not associated with significant depletion in amounts of cell-associated IgG detected in cell sonicates. Current studies are directed at ultrastructural monitoring of cell-associated IgG using peroxidase or ${ }^{125}$ I-labeled SLE gammaglobulins

TABLE VI

Effect of Aggregated IgG on Ig Association with Cultured T Cells

\begin{tabular}{cccc}
\hline \multirow{2}{*}{ Sera } & $\begin{array}{c}\text { Aggregated } \\
\text { IgG }\end{array}$ & IgG & IgM \\
\hline \multirow{3}{*}{ SLE } & & \multicolumn{2}{c}{$n g / 1 \times 10^{\circ}$ cells } \\
& 0 & 2,300 & 130 \\
& $100 \mu \mathrm{g} / \mathrm{ml}$ & 2,900 & 152 \\
& $500 \mu \mathrm{g} / \mathrm{ml}$ & 1,950 & 132 \\
& $1 \mathrm{mg} / \mathrm{ml}$ & 2,500 & 110 \\
NHS & $2 \mathrm{mg} / \mathrm{ml}$ & 2,850 & 112 \\
& 0 & 165 & 62 \\
& $100 \mu \mathrm{g} / \mathrm{ml}$ & 190 & 66 \\
& $1 \mathrm{mg} / \mathrm{ml}$ & 240 & 92 \\
\hline
\end{tabular}

- Different doses of heat-aggregated IgG $(100 \mu \mathrm{g} / \mathrm{ml}-2 \mathrm{mg} / \mathrm{ml})$ were added to one SLE serum. Aggregated IgG did not inhibit the capacity of this serum to associate with cultured $\mathrm{T}$ cells. 
TABLE VII

Effect of Rabbit Anti- $\beta_{2}$-microglobulin on Fc Rosette Formation and on IgG Cell Association after Incubation with SLE Sera

\begin{tabular}{|c|c|c|c|c|c|c|}
\hline \multicolumn{7}{|l|}{ Fc receptor function ${ }^{\circ}$} \\
\hline Rabbit anti- $\beta 2$-microglobulin & 0 & $100,000 \times$ & $10,000 \times$ & $1,000 \times$ & & $100 \times$ \\
\hline $\mathrm{T}$ cells, $\%$ & 5.7 & 3.5 & 0 & 0 & & 0 \\
\hline PBMC, \% & 9.5 & 5.0 & 2.5 & 0 & & 0 \\
\hline \multirow{2}{*}{ IgG cell association $\ddagger$} & & & IgG & & IgM & \\
\hline & & & \multicolumn{3}{|c|}{$\mathrm{ng} / 1 \times 10^{6} \mathrm{cells}$} & \\
\hline \multicolumn{3}{|l|}{ NHS } & $<10$ & & $<10$ & \\
\hline \multicolumn{3}{|c|}{+ Rabbit anti- $\beta_{2}$-microglobulin (100X) } & 12 & & $<10$ & \\
\hline \multicolumn{3}{|c|}{ SLE 1} & 2,400 & & 10 & \\
\hline \multicolumn{3}{|c|}{+ Rabbit anti- $\beta_{2}$-microglobulin $(50 \times)$} & 3,000 & & 16 & \\
\hline \multicolumn{3}{|l|}{ SLE 2} & 1,100 & & 52 & \\
\hline \multicolumn{3}{|c|}{+ Rabbit anti- $\beta_{2}$-microglobulin $(100 \times)$} & 1,600 & & 50 & \\
\hline
\end{tabular}

\begin{abstract}
- The effect of rabbit anti- $\beta_{2}$-microglobulin on Fc rosette formation was examined. T cells or PBMC were preincubated with several concentrations of rabbit anti- $\beta_{2}$-microglobulin for $30 \mathrm{~min}$ at $30^{\circ} \mathrm{C}$. After incubation, cells were washed and rosetted with sensitized ox erythrocytes. Rabbit anti- $\beta_{2}$-microglobulin could block Fc receptors.

$\downarrow \mathrm{T}$ cells were preincubated with rabbit anti- $\beta_{2}$-microglobulin at $37^{\circ} \mathrm{C}$ for $30 \mathrm{~min}$, which can completely block $\mathrm{Fc}$ receptors, as shown above. Then serum samples were added to the $\mathrm{T}$ cell suspensions. After 3 $\mathrm{d}$ of culture, $\mathrm{T}$ cell-associated Ig was measured. Rabbit anti- $\boldsymbol{\beta}_{2}$-microglobulin showed no effect.
\end{abstract}

to monitor the exact location of this extremely avid cell-reactive IgG present in some SLE sera. Serial studies of relative viability of cultured $T$ cells and SLE sera indicated lowest viabilities of cells after $4 \mathrm{~d}$ with sera containing IgG anti-T cell reactivity (Fig. 2A). These results supported the notion that cell-associated IgG acquired from such SLE sera was capable of eventually killing a considerable proportion of the cultured $\mathrm{T}$ cells. This occurred in the absence of added complement source.

It is not clear at present whether antibodies in SLE sera that react with intracellular components such as cytoplasmic or nuclear antigens might be involved in this IgG $\mathrm{T}$ cell association. This effect could be almost completely absorbed with intact living cells and IgG $\mathrm{T}$ cell association strongly correlated with IgG-anti-T cell cytotoxicity. Moreover, since MCTD sera with high titer ANA and no anti-T cell cytotoxicity showed neglible or slight IgG $T$ cell association, it would appear that these antibodies against intracellular components were not involved in the interaction with intact living cells. Nevertheless, it is possible that antibodies against intracellular antigens could enter cells after either cell membrane damage or altered permeability as a result of IgG anti-T cell antibody interaction with cell membranes. We observed that when heat-killed $\mathrm{T}$ cells ( $100 \%$ dead cells) were cultured in the presence of SLE sera, three to four times
TABLE VIII

Effect of Pepsin Digestion and Reduction and Alkylation of SLE Sera on Ig Association

(A)

\begin{tabular}{lcrr} 
& & \multicolumn{2}{c}{ Cell-association Ig } \\
\cline { 3 - 4 } & Pepsin digestion & IgG & IgM \\
\hline \multirow{2}{*}{ SLE 1 } & & \multicolumn{2}{c}{$n g / 1 \times 10^{\circ}$ cells } \\
& $(-)$ & 3,200 & 220 \\
SLE 2 & $(+)$ & 10 & 22 \\
& $(-)$ & 1,500 & 170 \\
SLE 3 & $(+)$ & 80 & 130 \\
& $(-)$ & 810 & 180 \\
NHS & $(+)$ & 50 & 90 \\
(B) & $(-)$ & 14 & 30 \\
& & & \\
\hline \multirow{2}{*}{ SLE 4 } & Reduction/alkylation & & \\
& $(-)$ & 3,000 & 550 \\
SLE 5 & $(+)$ & 620 & 130 \\
& $(-)$ & 1,700 & 600 \\
SLE 6 & $(+)$ & 560 & 120 \\
& $(-)$ & 1,400 & 90 \\
NHS & $(+)$ & 560 & 80 \\
& $(-)$ & 165 & 62 \\
\hline
\end{tabular}


TABLE IX

Effect of Cytochalasin B and Colchicine on Ig Association

\begin{tabular}{ccc}
\hline \multicolumn{1}{c}{ Sera } & $\operatorname{lgG}$ & IgM \\
\hline & $\begin{array}{c}n g / l \times 10^{\circ} \\
\text { cells }\end{array}$ & \\
SLE-1 & 2,300 & 130 \\
+ Cytochalasin B & 5,200 & 170 \\
+ Colchicine & 3,050 & 115 \\
SLE-2 & 800 & 26 \\
+ Cytochalasin B & 4,600 & 10 \\
+ Colchicine & 860 & 26 \\
NHS & 105 & 25 \\
+ Cytochalasin B & 140 & 10 \\
+ Colchicine & 75 & 34 \\
\hline
\end{tabular}

- T cells were preincubated with colchicine $(10 \mu \mathrm{M})$ or cytochalasin B $(10 \mathrm{mg} / \mathrm{ml})$ for $30 \mathrm{~min}$ at $37^{\circ} \mathrm{C}$ before the sera were added to the $\mathrm{T}$ cells.

the amount of $\mathrm{T}$ cell-associated IgG could be detected compared with living $T$ cell cultures. Dead cells cultured with NHS did not show any IgG T cell association. Our time sequence experiments, however, have demonstrated that IgG association occurred with the intact living $T$ cells and cell death followed as a result of, rather than a cause of, this phenomenon.

Immunochemical and functional studies of cell-reactive IgG in SLE sera studied here indicated that these antibodies were contained primarily within IgG rather than IgM fractions. Moreover, their presence in SLE sera appeared to correlate closely with anti-T cell cytotoxicity as measured by the conventional microcytotoxicity technique. Their primary $T$ cell specificity was also supported by the absorption studies using $T$ cells in parallel with other mononuclear cell preparations. Since non-T cells were also capable of absorbing reactive immunoglobulins, it is possible that antigens common to both $T$ and non- $T$ cells may also be involved.

One of the most interesting aspects of the reaction studied here relates to how the IgG SLE anti-T cell antibodies actually bind to and associate with the target cells. Prior blockade of cell $\mathrm{Fc}$ receptors either with heat-aggregated IgG or with dilute antibody to human $\beta_{2}$ microglobulin (32) did not inhibit SLE IgG ALA cell association. Moreover, the effects reported here were not analogous or the same as those reported for anti-RNP antibodies by Alarcon-Segovia et al. (2224), since such sera with high anti-RNP antibody titers did not show the cell-associating effect observed in the assays recorded here.

The cell associative reactivity of IgG anti-T cell an- tibody in SLE sera required the presence of the whole IgG molecule, since peptic digestion which reduced the antibodies to $F(a b)_{2}^{\prime}$ fragments completely eliminated effective $\mathrm{T}$ cell associating activity. In addition, reduction and alkylation of the SLE cell associating IgG completely eliminated the reaction. These findings appear to indicate that IgG cell association and perhaps ultimately cell penetration may in this case require both $\mathrm{T}$ cell reactivity by the IgG molecule and some other cell-adhesive mechanism not directly related to what are considered conventional cell surface Fc receptors. The precise nature of this reaction remains to be defined. Such IgG-cell membrane association and ultimate penetration may be directly related to the nature of the antigen on the $T$ cell surface reacting with the immunoglobulin (33). This may determine whether reactive complexes cap and move in a parallel plane within the cell membrane, or alternatively actually pass through the membrane into the cytosol of the target $T$ cell. It is of interest that the process defined here by SLE IgG ALA might eventually provide insight into previously unrecognized immunoglobulin cell surface reactions.

The results obtained for SLE IgG cell association before and after colchicine or cytochalasin $B$ cell treatment indicate that cell membrane capping and subsequent endocytosis may not be directly involved in the IgG cell association phenomenon. Relatively little change in cell association with IgG was recorded after colchicine treatment. However, increments in cell associated IgG after cytochalasin B treatment may indicate that cellular microfilaments as well as other cytoskeletal components may somehow be directly related to cell-IgG interaction. More work is needed to precisely define possible intracellular events involved.

IgM class of ALA are cold-reactive, complementdependent antibodies that, because of their cytotoxic capacity, have been implicated in the lymphopenia of SLE (34). Recently Kumagai et al. (35) have demonstrated the direct association of IgG ALA in cell lysis through sensitization of target cells in an antibodydependent cellular cytotoxicity system. In our study, serial viabilities of $T$ cells cultured with $T$ cell-reactive IgG demonstrated marked cell destruction at $7 \mathrm{~d}$. This phenomenon therefore represents another mechanism whereby warm reactive, complement-independent IgG ALA can cause cell death. This latter mechanism may represent an additional important factor in vivo in the lymphopenia of SLE.

The specificity of IgG anti-T cell reactions in SLE remains of considerable interest in terms of the basic immunoregulatory disorder associated with the disease itself. Whether such IgG antibodies are concerned with self down-modulation or elimination of antigen-spe- 
cific suppressor cells or whether they abrogate other portions of immune regulation remains to be determined.

\section{ACKNOWLEDGMENTS}

The authors are grateful to Ms. Kyoko Miyamoto for her technical assistance and to Ms. Susan Bonner for the preparation of the manuscript.

This work was supported in part by grants AMAI 13690 13, AMAI 13824-12, and 5K08 AM 00793-02 from the National Institutes of Health, and a grant from the Arthritis Foundation.

\section{REFERENCES}

1. Stastny, P., and M. Ziff. 1971. Direct lysis of lymphocytes by complement in patients with systemic lupus erythematosus. Arthritis Rheum. 14: 733-736.

2. Butler, W. T., F. T. Sharp, R. D. Rossen, M. D. Lidsky, K. K. Mittal, and D. A. Gard. 1972. Relationship of the clinical course of systemic lupus erythematosus to the presence of circulating lymphocytotoxic antibodies. Arthritis Rheum. 15: 231-238.

3. Winfield, J. B., R. J. Winchester, P. Wernet, S. M. Fu, and H. G. Kunkel. 1975. Nature of cold-reactive antibodies to lymphocyte surface determinants in systemic lupus erythematosus. Arthritis Rheum. 18: 1-8.

4. Williams, R. C., Jr., R. B. Lies, and R. P. Messner. 1973. Inhibition of mixed leukocyte culture responses by serum and $\gamma$-globulin fractions from certain patients with connective tissue disorders. Arthritis Rheum. 16: 597-605.

5. Wernet, P., and H. G. Kunkel. 1973. Antibodies to a specific surface antigen of $T$ cells in human sera inhibiting mixed leukocyte culture reactions. J. Exp. Med. 138: 1021-1026.

6. Horwitz, D. A., and J. B. Cousar. 1975. A relationship between impaired cellular immunity, humoral suppression of lymphocyte function, and severity of systemic lupus erythematosus. Am. J. Med. 58: 829-835.

7. Diaz-Jouanen, E., A. D. Bankhurst, R. P. Messner, and R. C. Williams, Jr. 1976. Serum and synovial fluid inhibitors of antibody-mediated lymphocytotoxicity in rheumatoid arthritis and systemic lupus erythematosus. Arthritis Rheum. 19: 142-149.

8. Diaz-Jouanen, E., A. D. Bankhurst, and R. C. Williams, Jr. 1976. Antibody-mediated lymphocytotoxicity in rheumatoid arthritis and systemic lupus erythematosus. Arthritis Rheum. 19: 133-141.

9. Feldman, J. L., M. J. Backer, H. Moutsolopulos, K. Fye, M. Blackman, W. V. Epstein, and N. Talal. 1976. Antibody-dependent cell-mediated cytotoxicity in selected autoimmune diseases. J. Clin. Invest. 58: 173-179.

10. Okudaira, K., K. Tanimoto, and Y. Horiuchi. 1981. Effect of antilymphocyte antibody in SLE on in vitro Ig synthesis. Clin. Immunol. Immunopathol. 21: 162-171.

11. Abdou, N. I., A. Sagawa, E. Pascual, J. Habert, and S. Sadeghee. 1976. Suppressor T-cell abnormality in idiopathic systemic lupus erythematosus. Clin. Immunol. Immunopathol. 6: 192-199.

12. Bresnihan, B., and H. E. Jasin. 1977. Suppressor function of peripheral blood mononuclear cells in normal individuals and in patients with systemic lupus erythematosus. J. Clin. Invest. 59: 106-116.
13. Morimoto, C. 1978. Loss of suppressor T-lymphocyte function in patients with systemic lupus erythematosus (SLE). Clin. Exp. Immunol. 32: 125-133.

14. Fauci, A. S., A. D. Steinberg, B. F. Haynes, and G. Whalen. 1978. Immunoregulatory aberrations in systemic lupus erythematosus. J. Immunol. 121: 14731479.

15. Sagawa, A., and N. T. Abdou. 1978. Suppressor-cell dysfunction in systemic lupus erythrematosus. J. Clin. Invest. 62: 789-796.

16. Sakane, T., A. D. Steinberg, and I. Green. 1978. Studies of immune functions of patients with systemic lupus erythematosus. I. Dysfunction of suppressor T-cell activity related to impaired generation of rather than response to suppressor cells. Arthritis Rheum. 21: 657-664.

17. Morimoto, C., T. Abe, T. Toguchi, M. Kiyotaki, and M. Homma. 1979. Studies of anti-lymphocyte antibody of patients with active SLE. 1. Cause of loss of suppressor T-lymphocyte function. Scand. J. Immunol. 10: 213221.

18. Sakane, T., A. D. Steinberg, J. P. Reeves, and I. Green. 1979. Studies of immune functions of patients with systemic lupus erythematosus. Complement-dependent immunoglobulin $M$ anti-thymus-derived cell antibodies preferentially inactivate suppressor cells. J. Clin. Invest. 63: 954-969.

19. Koike, T., S. Kobayashi, T. Yoshiki, T. Itoh, and T. Shirai. 1979. Differential sensitivity of functional subsets of $\mathrm{T}$ cells to the cytotoxicity of natural $\mathrm{T}$ lymphocytotoxic autoantibody of systemic lupus erythematosus. Arthritis Rheum. 22: 123-129.

20. Morimoto, C., E. L. Reinherz, T. Abe, M. Homma, and S. F. Schlossman. 1980. Characteristics of anti-T-cell antibodies in systemic lupus erythematosus: Evidence for selective reactivity with normal suppressor cells defined by monoclonal antibodies. Clin. Immunol. Immunopathol. 16: 474-484.

21. Morimoto, C., E. L. Reinherz, S. F. Schlossman, P. H. Schur, J. A. Mills, and A. D. Steinberg. 1980. Alterations in immunoregulatory $\mathrm{T}$ cell subsets in active systemic lupus erythematosus. J. Clin. Invest. 66: 1171-1174.

22. Alarcon-Segovia, D. A., A. Ruiz-Arguelles, and E. Fishbein. 1978. Antibody to nuclear ribonucleoprotein penetrates live human mononuclear cells through Fc-receptors. Nature (Lond.). 271: 67-69.

23. Alarcon-Segovia, D., A. Ruiz-Arguelles, and L. Llorente. 1979. Antibody penetration into T lymphocytes causing their deletion and the abrogation of suppressor function. Arthritis Rheum. 122: 1855-1862.

24. Alarcon-Segovia, D., A. Ruiz-Arguelles, and L. Llorente. 1979. Antibody penetration into living cells. II. Antiribonucleoprotein IgG penetrates into $\mathrm{T}$ lymphocytes causing their deletion and the abrogation of suppressor function. J. Immunol. 122: 1855-1862.

25. Cohen, A. S., W. E. Reynolds, E. C. Franklin, J. P. Kulka, M. W. Ropes, L. E. Shulman, and S. L. Wallace. 1971. Preliminary criteria for the classification of systemic lupus erythematosus. Bull. Rheum. Dis. 21: 643-648.

26. Boyum, A. 1978. Isolation of mononuclear cells and granulocytes from human blood. Scand. J. Clin. Lab. Invest. 21 (Suppl. 97): 77-90.

27. Okudaira, K., H. Nakai, T. Hayakawa, T. Kashiwado, K. Tanimoto, Y. Horiuchi, and T. Juji. 1979. Detection of antilymphocyte antibody with two-color method in systemic lupus erythematosus and its heterogeneous 
specificities against human $\mathrm{T}$-cell subsets. J. Clin. Invest. 64: 1213-1220.

28. Terasaki, P. L., and J. D. McClelland. 1964. Microdroplet assay of human cytotoxins. Nature (Lond.). 204: 9981000.

29. Abo, T., T. Yamaguchi, F. Shimizu, and K. Kumagai. 1976. Studies of surface innumoglobulins on human B lymphocytes. II. Characterization of a population of lymphocytes lacking surface immunoglobulin but carrying Fc receptor (SIg-Fct cell). J. Immunol. 117: 1781-1787.

30. Okudaira, K., K. Tanimoto, T. Nakamura, and Y. Horiuchi. 1980. Spontaneously enhanced in vitro immunoglobulin synthesis by B cells in systemic lupus erythematosus. Clin. Immunol. Immunopathol. 16: 267-278.

31. Searles, R. P., R. P. Messner, and S. M. Hermanson. 1981. Antilymphocyte antibodies in rheumatoid arthritis: increased reactivity against activated lymphocytes. Clin. Immunol. Immunopathol. 20: 246-254.
32. Morito, T., K. Tanimoto, Y. Horiuchi, and T. Juji. 1978. Fc-rosette inhibition by pregnant women's sera and by rabbit anti- $\beta_{2}$-microglobulin. Int. Arch. Allergy Appl. Immunol. 56: 247-255.

33. Williams, R. C., Jr., G. R. V. Hughes, M. L. Snaith, H. F. Parry, E. Diao, and M. F. Greaves. 1980. Lymphocyte antigens in systemic lupus erythematosus. Studies with heterologous antisera. J. Clin. Invest. 65: 379389.

34. Winfield, J. B., R. J. Winchester, and H. G. Kunkel. 1975. Association of cold-reactive antilymphocyte antibodies with lymphopenia in systemic lupus erythematosus. Arthritis Rheum. 18: 587-594.

35. Kumagai, S., A. D. Steinberg, and I. Green. 1981. Antibodies to $T$ cells in patients with systemic lupus erythematosus can induce antibody-dependent cell-mediated cytotoxicity against human $\mathrm{T}$ cells. J. Clin. Invest. 67: 605-614. 